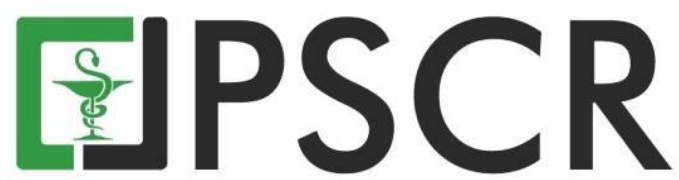

\title{
SKRINING AKTIVITAS ANTIBAKTERI EKSTRAK ETANOL DAUN TERHADAP Salmonella Typhi RESISTEN KLORAMFENIKOL
}

\author{
Ika Trisharyanti D.K. ${ }^{1 *}$, Rizmi Febriani ${ }^{1}$ \\ ${ }^{1}$ Fakultas Farmasi Universitas Muhammadiyah Surakarta \\ *email korespondensi: $\underline{\text { Ika.Trisharyanti@ums.ac.id }}$
}

\begin{abstract}
Abstrak : Demam tifoid merupakan penyakit yang disebabkan oleh Salmonella typhi. Antibiotik yang banyak digunakan untuk mengobati demam tifoid adalah kloramfenikol. Namun banyak dilaporkan terjadinya resistensi $S$. typhi terhadap antibiotik kloramfenikol, sehingga perlu pengobatan alternatif. Tujuan penelitian ini untuk mengetahui daya antibakteri ekstrak etanol sepuluh daun tanaman terhadap $S$. typhi resisten kloramfenikol, dan mengetahui golongan senyawa yang terkandung dalam ekstrak daun tanaman yang memiliki aktivitas antibakteri terbaik. Ekstraksi dilakukan dengan etanol $96 \%$ metode maserasi. Skrining daya antibakteri terhadap S. typhi menggunakan metode difusi disk dengan konsentrasi ekstrak daun tanaman sebesar $10 \%$. Ekstrak daun tanaman yang memiliki daya antibakteri terbaik ditentukan kadar bunuh minimal menggunakan metode dilusi cair. Uji identifikasi senyawa yang terkandung dianalisis dengan kromatografi lapis tipis (KLT), dan dilakukan uji bioautografi. Hasil yang diperoleh, ada 6 ekstrak yang memiliki aktivitas antibakteri terhadap S. typhi resisten kloramfenikol yaitu daun mahkota dewa, daun teh-tehan, daun kersen, daun cengkeh, daun teh, dan daun salam. Kadar bunuh minimal dari ekstrak daun cengkeh sebesar 2,5\%. Golongan enyawa yang terkandung dalam daun cengkeh adalah alkaloid, fenolik, flavonoid, terpenoid, triterpenoid, dan saponin. Berdasarkan hasil uji bioautografi diperkirakan senyawa yang dapat menghambat pertumbuhan bakteri $S$. typhi resisten kloramfenikol adalah senyawa golongan fenolik.
\end{abstract}

Abstract : Typhoid fever is an infectious disease caused by Salmonella typhi, antibiotic chloramphenicol can be use to treatment, but S. typhi resistant with antibiotic choramphenicol so need to alternative treatment. The purpose of this study was to determine the antibacterial activity of ethanol extract of ten leaves against Salmonella typhi, and knowing the compounds contained in extracts of leaves that have the best antibacterial activity. The leaves was extracted with ethanol $96 \%$ by maceration method. Screening antibacterial activity used disk diffusion method with $10 \%$ extract concentration. The best antibacterial activity was determined Minimum Inhibitory Concentration and Minimum Bactericidal Concentration used liquid dilution method, identification test of compounds with thin-layer chromatograpy (TLC), and bioautografi test. There were six extracts had antibacterial activity against S. Typhi, Phaleria 
macrocarpa leaves, Acalypha siamensis leaves, cherry leaves, clove leaves, tea leaves, and Eugenia polyantha leaves. Minimum Bactericidal Concentration from clove leaf extract was 2,5\%. The results of identification by TLC compounds were alkaloids, phenolics, flavonoids, terpenoids, triterpenoids, and saponins. Based on bioautografi test, phenolic can inhibit the growth of Salmonella typhi.

Keywords: Antibacterial, Salmonella typhi, TLC, Bioautografi

\section{Pendahuluan}

Salmonella typhi adalah bakteri penyebab demam tifoid. Penyakit ini menyerang hampir disemua negara, terutama di negara-negara berkembang seperti Indonesia. Angka kejadian demam tifoid tergantung dari banyak hal diantaranya kebersihan lingkungan dan perilaku masyarakat. Prevalensi angka kejadian demam tifoid di Amerika Latin berkisar antara 150/10.000 penduduk per tahunnya, sedangkan prevalensi di Asia jauh lebih tinggi yakni 900/10.000 penduduk setiap tahun (Widoyono, 2008). Di Indonesia angka kejadian demam tifoid sebesar $1,5 \%$ yang artinya terdapat kasus demam tifoid 1.500/100.000 penduduk Indonesia (Herawati and Ghani, 2009).

Penanganan penyakit demam tifoid secara medis masih menggunakan prinsip trilogi yaitu istirahat, diet, dan antimikroba. Obat yang digunakan sebagai pilihan pertama demam tifoid adalah antibiotik kloramfenikol, namun banyak dilaporkan adanya resistensi S. typhi terhadap antibiotik kloramfenikol (Sondang dan Satari, 2010). Pengobatan dari bahan-bahan alami yang berasal dari tumbuhan diperlukan sebagai solusi pengobatan demam tifoid. Menurut Hedi (2007) bahan alami dari tumbuhan yang mengandung zat aktif seperti alkaloid, flavonoid, tanin, saponin, dan terpen memiliki efek terapeutik yang dapat dimanfaatkan untuk pengobatan. Tanaman yang telah diteliti dan memiliki aktivitas antibakteri adalah daun mahkota dewa (Shodikin, 2010), daun teh-tehan (Wiart et al., 2004), daun pepaya (Suresh et al., 2008), daun jati belanda (Ivana et al., 2012), daun jeruk purut (Yuliani et al., 2011), daun kersen (Prasetyo dan Sasongko, 2014), daun cengkeh (Kumala dan Indriani, 2008), daun teh (Astuningsih et al., 2014), daun mengkudu (Sukandar et al., 2010), dan daun salam (Lau et al., 2014).

Ekstrak etanol daun mahkota dewa memiliki efek antibakteri pada bakteri Pseudomonas aeruginosa (Shodikin, 2010). Ekstrak metanol daun teh-tehan mampu menghambat pertumbuhan bakteri $S$. aureus dengan diameter zona hambat sebesar 11 mm (Wiart et al., 2004). Ekstrak daun pepaya dapat menghambat pertumbuhan bakteri E. coli dengan diameter zona hambat 3,4 $\mathrm{mm}$ dan pada $S$. aureus dengan diameter zona hambat 3,6 mm dengan Konsentrasi Hambat Minimal sebesar $25 \mu \mathrm{l} / \mathrm{mL}$ (Suresh et al., 2008). Ekstrak daun jati belanda memiliki efek antibakteri terhadap E. coli dan Pseudomonas aeruginosa dengan Konsentrasi Hambat Minimal sebesar $25 \mathrm{mg} / \mathrm{mL}$ (Ivana et al., 2012). Daun jeruk purut mengandung minyak atsiri yang dapat menghambat dan membunuh bakteri S. aureus dan E. coli (Yuliani et al., 2011).

Ekstrak etanol daun kersen memiliki aktivitas antibakteri terhadap bakteri Bacillus subtilis dengan Konsentrasi Bunuh Minimal sebesar 6,25\% dan bakteri Shigella dysenteriae dengan Konsen 
trasi Bunuh Minimal sebesar 3,125\% (Prasetyo dan Sasongko, 2014). Ekstrak etanol daun cengkeh pada konsentrasi $10 \%$ memiliki efek antibakteri terhadap bakteri $S$. aureus, B. subtilis, E. coli, dan S. paratyphi (Kumala dan Indriani, 2008). Daun teh mengandung senyawa katekin yang dapat menghambat pertumbuhan $S$. aureus dengan Konsentrasi Hambat Minimal sebesar 12,5\% (Astutiningsih et al., 2014). Ekstrak butanol daun mengkudu dapat menghambat pertumbuhan bakteri B. cereus, B. subtilis, dan bakteri $P$. aeruginosa dengan zona hambat $15-20 \mathrm{~mm}$ (Sukandar et al., 2010). Ekstrak daun salam dapat menghambat pertumbuhan bakteri B. cereus dengan KHM sebesar $0,31 \mathrm{mg} / \mathrm{mL}$ dan bakteri B. subtilis dengan KHM sebesar 0,63 mg/mL (Lau et al., 2014).

Penelitian ini dilakukan untuk mengetahui aktivitas antibakteri terhadap $S$. typhi resisten kloramfenikol dan mengetahui golongan senyawa yang memiliki aktivitas antibakteri terbaik. Sampel yang digunakan adalah ekstrak etanol $96 \%$ daun mahkota dewa (Phaleria macrocarpa), daun teh-tehan (Acalypha siamensis), daun pepaya (Carica papaya L.), daun jati belanda (Guazoma ulmifolia L.), daun jeruk purut (Citrus hystrix), daun kersen (Muntingia calabura L.), daun cengkeh (Syzygium aromaticum), daun teh (Camellia sinensis L.), daun mengkudu (Morinda citrifolia), dan daun salam (Eugenia polyantha).

\section{Metodologi Penelitian}

\subsection{Ekstraksi}

Lima puluh gram sampel serbuk daun dimaserasi dengan $375 \mathrm{~mL}$ etanol $96 \%$ (perbandingan 1:7,5) selama $3 \times 24$ jam, kemudian disaring menggunakan corong buchner dan selanjutnya disaring kembali dengan kertas saring. Ampas hasil maserasi kemudian diremaserasi sebanyak $2 \mathrm{x}$ dengan pelarut yang sama. Filtrat dari masingmasing sampel dipekatkan dengan menggunakan evaporator. Hasil evaporator kemudian diuapkan dengan penangas air hingga diperoleh ekstrak yang kental.

\subsection{Identifikasi Bakteri}

Sesuai dengan Kusumowati, et al., 2017.

\subsection{Uji Sensitivitas Bakteri Terhadap Antibiotik}

Sesuai dengan Kusumowati, et.al., 2017.

\subsection{Pembuatan Konsentrasi Sampel}

Sesuai dengan Kusumowati, et al., 2017.

\subsection{Skrining Aktivitas Antibakteri}

Sesuai dengan Kusumowati, et.al., 2017.

\subsection{Penentuan KHM dan KBM}

Sesuai dengan Kusumowati, et.al., 2017.

\subsection{Identifikasi Senyawa dengan KLT}

Sesuai dengan Kusumowati, et.al., 2017.

\subsection{Bioautografi}

Sesuai dengan Kusumowati, et.al., 2017. 


\subsection{Analisis Data}

Analisis hasil skrining aktivitas antibakteri ekstrak etanol sepuluh daun tanaman dilakukan dengan mengamati zona jernih yang terbentuk disekitar disk, ekstrak yang memiliki aktivitas antibakteri terbaik ditandai dengan terbentuk zona hambat tertinggi. Penentuan KHM ditandai dengan kejernihan pada larutan uji yakni konsentrasi terendah yang dapat menghambat pertumbuhan bakteri. Pengamatan KBM dilakukan dengan mengamati hasil dilusi cair yang ditanam pada media agar, konsentrasi terkecil pada media yang tidak terdapat pertumbuhan bakteri disebut KBM. Analisis KLT dengan cara mengamati hasil elusi plat KLT pada sinar tampak, UV $254 \mathrm{~nm}, 366 \mathrm{~nm}$ serta mengamati perubahan yang terjadi setelah disemprot dengan pereaksi semprot, hasil yang diperoleh dibandingkan dengan teori atau hasil penelitian sebelumnya. Analisis bioautografi dilakukan dengan mengamati zona jernih yang terbentuk lalu dicocokkan dengan hasil elusi KLT untuk menentukan senyawa yang memiliki aktivitas antibakteri.

\section{Hasil dan Pembahasan}

\subsection{Ekstraksi}

Ekstrak kental sepuluh daun diperoleh dengan ekstraksi menggunakan metode maserasi dengan pelarut etanol 96\%. Hasil rendemen yang diperoleh dari 10 simplisia daun bervariasi, rendemen tertinggi adalah daun mahkota dewa sebesar 19,1820\% dan rendemen terendah adalah daun jati belanda sebesar 5,8175\%. Hasil ekstraksi 10 sampel daun dapat dilihat pada Tabel 1.

Tabel 1. Hasil ekstraksi sepuluh daun tanaman

\begin{tabular}{|l|c|c|c|}
\hline \multicolumn{1}{|c|}{ Sampel } & $\begin{array}{c}\text { Bobot Serbuk } \\
\text { (gram) }\end{array}$ & $\begin{array}{c}\text { Bobot Ekstrak } \\
\text { (gram) }\end{array}$ & $\begin{array}{c}\text { Rendemen } \\
(\mathbf{\%} \text { b/b) }\end{array}$ \\
\hline Daun jati belanda & 50,1413 & 2,9170 & 5,8175 \\
\hline Daun salam & 50,0298 & 3,3790 & 6,7539 \\
\hline Daun pepaya & 50,2605 & 4,5200 & 8,9931 \\
\hline Daun jeruk purut & 50,0615 & 4,7560 & 9,5000 \\
\hline Daun kersen & 50,0415 & 5,4393 & 10,8695 \\
\hline Daun teh-tehan & 50,1150 & 5,5803 & 11,1343 \\
\hline Daun mengkudu & 50,0999 & 6,4778 & 12,9297 \\
\hline Daun teh & 50,0676 & 6,4953 & 12,9730 \\
\hline Daun cengkeh & 50,1327 & 8,9242 & 17,8011 \\
\hline Daun mahkota dewa & 50,0948 & 9,6092 & 19,1820 \\
\hline
\end{tabular}

\subsection{Identifikasi Bakteri}

Identifikasi bakteri dilakukan dengan pengecatan Gram dan uji biokimiawi. Pengecatan Gram digunakan untuk membedakan golongan Gram negatif dan golongan Gram positif dengan menggunakan cat Gram. Hasil pengecatan Gram menunjukan, bakteri Salmonella typhi berwarna merah yang menandakan bakteri termasuk golongan Gram negatif, berbentuk batang dan menyebar, hasil pengamatan sudah sesuai dengan teori yang menyatakan bahwa Salmonella typhi merupakan bakteri Gram negatif yang berbentuk batang.

Identifikasi bakteri dengan uji biokimia menggunakan media KIA, LIA, dan SIM. Hasil yang diperoleh pada media KIA pada bagian tegak dan miring berwarna 
merah yang menunjukkan bakteri tidak memfermentasi glukosa dan laktosa bagian bawah media terlihat warna hitam hal ini menunjukkan bakteri menghasilkan $\mathrm{H}_{2} \mathrm{~S}$. Hasil yang diperoleh pada media LIA, media tetap berwarna ungu yang menunjukan $\mathrm{pH}$ alkali dan bakteri mendekarboksilasi lisin, serta bakteri membentuk $\mathrm{H}_{2} \mathrm{~S}$ ditandai dengan warna hitam pada bagian bawah media. Hasil yang diperoleh pada media SIM, media menjadi keruh dengan penyebaran yang merata tidak hanya pada bekas tusukan inokulum bakteri, hal ini menunjukkan bakteri ini memiliki flagel, serta perubahan warna media menjadi hitam menunjukkan bakteri menghasilkan $\mathrm{H}_{2} \mathrm{~S}$.

\subsection{Uji Sensitivitas Bakteri Terhadap Antibiotik}

Uji sensitivitas bakteri $S$. typhi terhadap antibiotik menggunakan beberapa disk antibiotik, diantaranya antibiotik kloramfenikol $30 \mu \mathrm{g}$, sefotaksim $30 \mu \mathrm{g}$, seftriakson $30 \mu \mathrm{g}$, dan sefiksim $5 \mu \mathrm{g}$. Dari hasil yang diperoleh bakteri $S$. typhi sensitif terhadap antibiotik seftriakson, resisten terhadap antibiotik kloramfenikol, serta menghasilkan aktivitas intermediet terhadap antibiotik sefotaksim dan sefiksim. Hasil selengkapnya ada di tabel 2. Hasil uji sensitivitas menunjukkan bahwa bakteri Salmonella typhi yang digunakan resisten terhadap antibiotik kloramfenikol. Resistensi terhadap kloramfenikol dapat terjadi melalui perubahan target (ribosom) dari antibiotika, dihasilkannya inaktivator berupa enzim kloramfenikol asetil transferase dan mekanisme yang membatasi antibiotika masuk secara terus menerus melalui membran luar serta akan memompa keluar antibiotika dari sitoplasma (Yatnita, 2011).

Tabel 2. Uji sensitivitas bakteri $S$. typhi terhadap antibiotik

\begin{tabular}{lccccl}
\hline \multirow{2}{*}{ Antibiotik } & \multicolumn{3}{c}{ Diameter zona hambat $(\mathrm{mm})$} & $\begin{array}{c}\text { Diameter } \\
\text { zona hambat } \\
\text { uji }(\mathrm{mm})\end{array}$ & $\begin{array}{l}\text { Sifat } \\
\text { bakteri }\end{array}$ \\
\cline { 2 - 5 } & Resisten & Intermediet & Sensitif & & \multicolumn{1}{c}{ ban } \\
Kloramfenikol $(30 \mu \mathrm{g})$ & $\leq 12$ & $13-17$ & $\geq 18$ & 6 & Resisten \\
Sefotaksim $(30 \mu \mathrm{g})$ & $\leq 22$ & $23-25$ & $\geq 26$ & 24 & Intermediet \\
Seftriakson $(30 \mu \mathrm{g})$ & $\leq 19$ & $20-22$ & $\geq 23$ & 28 & Sensitif \\
Sefiksim $(5 \mu \mathrm{g})$ & $\leq 15$ & $16-18$ & $\geq 26$ & 18 & Intermediet \\
\hline
\end{tabular}

(Clinical and Laboratory Standard Institute (CLSI), 2011

\subsection{Skrining Aktivitas Antibakteri}

Skrining aktivitas antibakteri dilakukan dengan menggunakan metode disc diffusion, dengan tujuan mengetahui kemampuan ekstrak etanol daun tanaman dalam menghambat bakteri S. typhi. Konsentrasi ekstrak yang digunakan pada tahap skrining adalah $10 \%$ (1 mg/disk). Dari sepuluh ekstrak daun yang diuji, terdapat enam ekstrak daun yang memiliki daya hambat, yaitu daun mahkota dewa, daun teh-tehan, daun kersen, daun cengkeh, daun teh, serta daun salam.

Diantara 6 ekstrak yang memiliki zona hambat, hanya daun cengkeh dan daun kersen yang menghasilkan zona radikal. Selain ekstrak tanaman, pada uji skrining ini juga menguji seftriakson sebagai kontrol positif dan DMSO sebagai kontrol negative. Penggunaan seftriakson sebagai kontrol positif karena seftriakson merupakan antibiotik berspektrum luas yang kuat melawan pertumbuhan bakteri batang gram negatif seperti Salmonella typhi (Jawetz et al., 2001), secara klinis seftriakson digunakan untuk pilihan terapi yang poten pada pengobatan demam tifoid dan memiliki tingkat resistensi yang masih terbatas (Lili et al., 2004). Penggunaan DMSO karena DMSO dapat melarutkan ekstrak etanol daun tanaman dengan baik. Hasil skrining aktivitas antibakteri dapat dilihat pada Tabel 3. 
Tabel 3. Hasil diameter zona hambat skrining antibakteri 10 ekstrak daun tanaman

\begin{tabular}{|l|l|}
\hline \multicolumn{1}{|c|}{ Sampel } & \multicolumn{1}{|c|}{ Rata-rata zona hambat $(\mathbf{m m}) \pm$ SD } \\
\hline K $-($ DMSO) & $6,00 \pm 0$ \\
\hline Ekstrak daun jatibelanda & $6,00 \pm 0$ \\
\hline Ekstrak daun jeruk purut & $6,00 \pm 0$ \\
\hline Ekstrak daun mengkudu & $6,00 \pm 0$ \\
\hline Ekstrak daun pepaya & $6,00 \pm 0$ \\
\hline Ekstrak daun mahkota dewa & $9,00 \pm 1,00$ \\
\hline Ekstrak daun salam & $10,00 \pm 0$ \\
\hline Ekstrak daun teh & $10,16 \pm 2,25$ \\
\hline Ekstrak daun teh-tehan & $13,50 \pm 1,50$ \\
\hline Ekstrak daun kersen & $13,67 \pm 1,52^{\mathrm{R}}$ \\
\hline Ekstrak daun cengkeh & $14,50 \pm 0,28^{\mathrm{R}}$ \\
\hline K+ (sefriakson 30 $\mu \mathrm{g})$ & $30,16 \pm 0,28$ \\
\hline
\end{tabular}

Keterangan : Diameter zona hambat termasuk diameter disk $(6 \mathrm{~mm})$

$\mathrm{R}$ : Radikal

Hasil di atas merupakan hasil 3x replikasi

Hasil skrining dari tabel 1 dapat dilihat bahwa ekstrak yang mempunyai diameter terbesar adalah ekstrak daun cengkeh, dengan zona hambat 14,50 $\mathrm{mm}$ dan menunjukkan zona radikal. Berdasarkan hasil yang diperoleh menunjukkan bahwa ekstrak daun cengkeh memiliki sifat antibakteri, dugaan ini karena dalam daun cengkeh mengandung minyak atsiri yang komponen utamanya adalah eugenol.

\subsection{Penentuan KHM dan KBM}

Penentuan KHM bertujuan untuk mengetahui konsentrasi terendah ekstrak daun yang dapat menghambat pertumbuhan bakteri. Penentuan KBM bertujuan untuk mengetahui konsentrasi terendah dari ekstrak daun yang dapat membunuh pertumbuhan bakteri. Pada uji ini digunakan tiga kontrol yaitu kontrol pertumbuhan bakteri, kontrol media, dan kontrol pelarut. Kontrol pertumbuhan digunakan untuk memastikan bahwa bakteri $S$. typhi dapat tumbuh dengan baik pada media yang digunakan. Kontrol media BHI bertujuan untuk memastikan sterilitas media serta mengetahui ada dan tidaknya kontaminasi dalam media yang digunakan. Kontrol pelarut menggunakan DMSO untuk memastikan bahwa DMSO tidak memiliki daya antibakteri terhadap S. typhi.

Penentuan KHM dilakukan dengan cara dilusi cair dengan berbagai konsentrasi ekstrak sampel, sampel yang digunakan pada tahap ini adalah daun cengkeh karena memiliki daya antibakteri terhadap $S$. typhi paling baik, dengan menggunakan konsentrasi uji 20\%, 10\%, 5\%, 2,5\%, dan 1,25\%. Hasil yang diperoleh nilai KHM tidak dapat ditentukan, hal ini karena warna dari ekstrak yang diuji berwarna hijau kehitaman sehingga sulit untuk mengamati langsung kekeruhan dan kejernihan larutan.

Penentuan KBM dilakukan dengan cara menggoreskan hasil dilusi cair pada media $\mathrm{MH}$ agar pada tabung reaksi. HAsil yang diperoleh pada konsentrasi $1,25 \%$ masih terdapat pertumbuhan bakteri, sedangkan pada konsentrasi 2,5\% hingga konsentrasi $20 \%$ tidak terdapat pertumbuhan bakteri. Hal ini menunjukkan bahwa pada konsentrasi 2,5\% hingga $20 \%$ ekstrak daun cengkeh dapat membunuh bakteri S. typhi, 
sehingga dapat disimpulkan KBM dari ekstrak daun cengkeh terdapat pada konsentrasi 2,5\%. Hasil pengamatan KBM ekstrak daun cengkeh dapat dilihat pada Tabel 4.

Tabel 4. Hasil pengamatan KBM ekstrak daun cengkeh

Keterangan :

\begin{tabular}{|c|c|}
\hline Tabung uji & Hasil \\
\hline Ekstrak 20\% & - \\
\hline Ekstrak 10\% & - \\
\hline Ekstrak 5\% & - \\
\hline Ekstrak 2,5\% & - \\
\hline Ekstrak1,25\% & + \\
\hline Kontrol pertumbuhan & + \\
\hline Kontrol media & - \\
\hline Kontrol pelarut & - \\
\hline
\end{tabular}

$+\quad$ : ada pertumbuhan

- $\quad$ : tidak ada pertumbuhan

\subsection{Analisis Kromatografi Lapis Tipis}

Tujuan dari analisis KLT adalah mengetahui senyawa yang terkandung dalam ekstrak etanol daun tanaman. Sampel yang dianalisis adalah daun cengkeh, etanol pa digunakan sebagai pelarut, dengan fase gerak n-heksan : etil asetat (6:4), dan fase diam silika gel $\mathrm{GF}_{254}$. Hasil analisis senyawa yang terkandung dalam ekstrak daun dengan KLT berdasarkan reaksi berbagai senyawa dengan pereaksi semprot Dragendorff, sitroborat, $\mathrm{FeCl}_{3}$, anisaldehid, Liebermann-burchard, dan vanillin- $\mathrm{H}_{2} \mathrm{SO}_{4}$.

Dragendroff digunakan untuk mengindentifikasi adanya alkaloid, hasil positif alkaloid ditandai dengan bercak berwarna oranye hingga coklat pada sinar tampak (Wagner and Bladt, 1996). Hasil yang diperoleh pada ekstrak daun cengkeh positif mengandung alkaloid yang ditunjukan dengan bercak berwarna coklat setelah disemprot dengan Dragendroff. $\mathrm{FeCl}_{3}$ digunakan untuk mengidentifikasi adanya fenolik yang terkandung dalam ekstrak, hasil positif fenolik ditandai dengan bercak berwarna abuabu kehitaman yang diamati pada sinar tampak setelah disemprot dengan $\mathrm{FeCl}_{3}$ (Harborne, 1987). Hasil yang diperoleh setelah disemprot dengan $\mathrm{FeCl}_{3}$ pada ekstrak daun cengkeh menunjukan hasil positif adanya fenolik yang ditandai dengan timbulnya bercak abu-abu kehitaman.

Sitroborat digunakan untuk mengidentifikasi adanya flavonoid yang terkandung dalam ekstrak, pengamatan dilakukan dibawah sinar UV $366 \mathrm{~nm}$, flavonoid ditunjukan dengan timbulnya bercak yang berfluoresensi hijau, hijau kuning, atau biru keunguan setelah disemprot dengan sitroborat, sebelum diamati plat KLT terlebih dahulu dikeringkan dalam oven pada suhu $110^{\circ} \mathrm{C}$ selama 10 menit (Harborne, 1987). Daun cengkeh positif mengandung flavonoid yang ditandai timbulnya bercak berfluoresensi biru keunguan setelah disemprot dengan sitroborat.

Anisaldehid digunakan untuk mengidentifikasi adanya triterpenoid yang terkandung dalam ekstrak, hasil positif triterpenoid dalam sampel ditandai dengan bercak berwarna biru, ungu serta merah keunguan pada sinar tampak setelah disemprot dengan anisaldehid, pengamatan dilakukan setelah plat KLT dikeringkan dalam oven pada suhu $110^{\circ} \mathrm{C}$ selama 10 menit (Wagner and Bladt, 1996). Hasil yang diperoleh pada ekstrak daun cengkeh timbul bercak warna ungu setelah disemprot dengan anisaldehid. 
Vanillin- $\mathrm{H}_{2} \mathrm{SO}_{4}$ dapat digunakan untuk mendeteksi adanya terpenoid pada ekstrak, timbulnya bercak berwarna merah, coklat, ungu, biru, dan abu-abu setelah disemprot vanillin- $\mathrm{H}_{2} \mathrm{SO}_{4}$ menandakan adanya terpenoid yang terkandung dalam ekstrak (Wagner and Bladt, 1996). Perubahan warna bercak menjadi coklat timbul setelah disemprot dengan vanillin- $\mathrm{H}_{2} \mathrm{SO}_{4}$ pada ekstrak daun cengkeh, hal ini menunjukkan ekstrak daun cengkeh mengandung terpenoid.

Liebermann-Burchard digunakan untuk mendeteksi adanya saponin yang terkandung dalam ekstrak, saponin dapat dibedakan menjadi dua yakni saponin steroid dan saponin triterpenoid. Timbulnya warna bercak setelah disemprot LB menjadi hijau kebiruan menunjukkan adanya saponin steroid, sedangkan bercak berwarna merah muda dan ungu menunjukkan adanya saponin triterpenoid (Farnsworth, 1966). Pada hasil elusi daun cengkeh timbul bercak hijau kebiruan setelah disemprot dengan LB, hal ini menunjukkan daun cengkeh mengandung saponin.

Berdasarkan hasil analisis KLT diperkirakan senyawa yang terkandung dalam daun cengkeh adalah alkaloid, fenolik, flavonoid, triterpenoid, terpenoid dan saponin. Hasil penelitian ini sesuai dengan penelitian sebelumnya yang dilakukan Devi et al., (2012) yang menyatakan bahwa daun cengkeh mengandung fenolik, flavonoid, dan proantosianidin sedangkan menurut Talahatu dan Papilaya (2015) daun cengkeh mengandung saponin, alkaloid, flavonoid glikosida, tanin. Hasil analisis KLT dapat dilihat di tabel 5.

\section{Tabel 5. Hasil analisis KLT ekstrak etanol daun cengkeh}

\begin{tabular}{|c|c|c|c|c|c|c|c|c|c|c|}
\hline \multirow{3}{*}{ hRf } & \multirow{3}{*}{ Visibel } & \multicolumn{8}{|c|}{ Warna bercak } & \multirow{3}{*}{ Keterangan } \\
\hline & & \multicolumn{2}{|c|}{ Sinar UV } & Dragendr & $\mathrm{FeCl}_{3}$ & Sitroborat & Anisaldehid & $\begin{array}{c}\text { Vanillin- } \\
\mathrm{H}_{2} \mathrm{SO}_{4}\end{array}$ & LB & \\
\hline & & $254 \mathrm{~nm}$ & $366 \mathrm{~nm}$ & VIS & VIS & UV-366 & VIS & VIS & VIS & \\
\hline 32 & $\mathrm{~K}$ & - & - & & - & - & - & - & - & - \\
\hline 48 & - & - & M & - & - & - & $\mathrm{Hj}$ & - & - & - \\
\hline 52 & - & - & M & - & & - & - & - & & - \\
\hline 56 & - & - & - & - & - & - & - & - & - & - \\
\hline 60 & $\mathrm{~K}$ & $\mathrm{P}$ & B & - & - & $\mathrm{U}$ & $\mathrm{U}$ & - & - & Flavonoid,triterpenoid \\
\hline 66 & $\mathrm{~K}$ & $\mathrm{P}$ & B & - & - & - & - & $\mathrm{C}$ & - & Terpenoid \\
\hline 70 & - & - & - & $\mathrm{C}$ & - & $\mathrm{U}$ & - & $\mathrm{C}$ & - & $\begin{array}{l}\text { Alkaloid,flavonoid, } \\
\text { terpenoid }\end{array}$ \\
\hline 78 & $\mathrm{Ht}$ & - & M & $\mathrm{Hj}$ & $\mathrm{AH}$ & - & - & - & $\mathrm{K}$ & Fenolik \\
\hline 84 & - & $\mathrm{P}$ & - & - & - & M & $\mathrm{U}$ & - & B & Saponin, triterpenoid \\
\hline 96 & $\mathrm{~K}$ & $\mathrm{P}$ & M & - & - & M & - & - & - & - \\
\hline
\end{tabular}

$$
\text { Keterangan: } \begin{aligned}
\mathrm{Hj} & =\text { Hijau } \\
\mathrm{M} & =\text { Merah } \\
\mathrm{Ht} & =\text { Hitam }
\end{aligned}
$$

$$
\begin{aligned}
& \mathrm{K}=\text { Kuning } \\
& \mathrm{C}=\text { Coklat } \\
& \mathrm{AH}=\text { Abu-abu kehitaman }
\end{aligned}
$$

$$
\begin{aligned}
\mathrm{B} & =\text { Biru } \\
\mathrm{P} & =\text { Padam } \\
\mathrm{U} & =\text { Ungu }
\end{aligned}
$$

\subsection{Bioautografi}

Hasil uji bioautografi menunjukkan adanya zona jernih yang timbul pada hRf 78 , hal ini menandakan adanya daya antibakteri yang terdapat pada bercak, senyawa yang terkandung pada hRf 78 adalah golongan fenolik. Namun belum dapat diketahui secara pasti senyawa fenolik tersebut.

Menurut Alitonou et al. (2012), senyawa aktif antibakteri dalam daun cengkeh adalah eugenol $(60,4 \%)$, dan trans- $\beta$-caryophyllene $(24,0 \%)$, yang terbukti dapat menghambat pertumbuhan E. Coli dengan Konsentrasi Hambat Minimal sebesar $0,20 \pm 0,01 \mathrm{mg} / \mathrm{mL}$ dan menghambat pertumbuhan $S$. aureus dengan Konsentrasi Hambat Minimal sebesar 0,025 $\pm 0,002 \mathrm{mg} / \mathrm{mL}$. Menurut Kumala dan Indriani (2008), eugenol bersifat lipofilik yang dapat menyebabkan terjadinya adhesi pada membran sel bakteri 
yang mengakibatkan tekanan osmotik bakteri meningkat, sehingga terjadi kerusakan pada membran sel bakteri serta menghambat proses respirasi bakteri. Terhambatnya proses respirasi bakteri menyebabkan timbulnya gangguan transpor ion pada sel bakteri sehingga bakteri akan mengalami kematian. Selain eugenol, menurut Meiske et al., (2014) daun cengkeh juga mengandung senyawa fenolik lainnya seperti asam galat, kuersetin, rutin, dan kaemferol. Hasil bioautografi dapat dilihat pada Gambar 1.

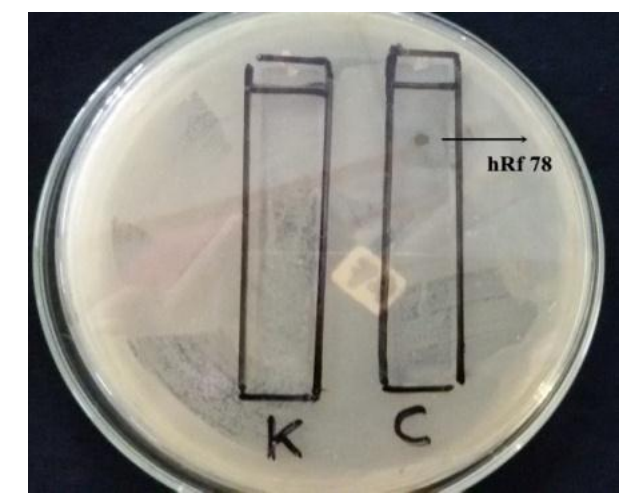

\section{Gambar 1. Hasil bioautografi ekstrak daun cengkeh \\ K : Kontrol; C : Ekstrak daun cengkeh}

\section{Kesimpulan}

Hasil skrining aktivitas antibakteri dengan konsentrasi $10 \%$ menunjukan terdapat 6 ekstrak etanol daun yang memiliki aktivitas antibakteri terhadap $S$. typhi resisten kloramfenikol yakni daun mahkota dewa, daun salam, daun teh, daun teh-tehan, daun kersen, dan daun cengkeh, dengan rata-rata diameter zona hambat sebesar 9,00 $\pm 1,00$ $\mathrm{mm} ; 10,00 \pm 00 \mathrm{~mm} ; 10,16 \pm 2,25 \mathrm{~mm} ; 13,50 \pm 50 \mathrm{~mm} ; 13,67 \pm 1,52 \mathrm{~mm}$; dan $14,50 \pm 0,28$ $\mathrm{mm}$. Berdasarkan uji bioautografi menunjukkan bahwa kemungkinan senyawa aktif yang memiliki daya antibakteri adalah golongan fenolik.

\section{Daftar Pustaka}

Alitonou G.A., Tchobo F.P., Avlessi F., Yehounou B., Yedomonhan P., Koudoro A.Y.,Menut Chantal., 2012. Chemical and biological investigations of Syzygium aromaticum L. Essential Oil from Benin. International Journal Biologi Chemicalscience. 6 (3). 1360-1367.

Astutiningsih C., Setyani W., Hindratna H., 2014. Uji Daya Antibakteri dan Identifikasi Isolat Senyawa Katekin dari Daun Teh (Camellia sinensis L.var Assamica). Jurnal Farmasi Sains dan Kominitas. 11 (2), 50-57.

Clinical and Laboratory Standard Institute (CLSI), 2011, Performance Standards for Antimicrobial Susceptibility Testing; 21th Informational Supplement.

Devi S.A., Umasankar M.E., Babu S., 2012. A Comparative Study Of Anti Oxidant Properties In Common Indian Spices. International Research Journal Of Pharmacy. 3 (5), 465-468. 
Hedi. D.R., 2007. Pengembangan Obat Tradisional Indonesia Menjadi Fitofarmaka. Majalah Kedokteran Indonesia. 57 (7), 205-211.

Farnsworth N.R., 1966. Biological and Phytochemical Screening of Plants. Journal of Pharmaceutical Science. 55 (3), 225-276.

Harborne J.B., 1987. Metode Fitokimia: Penuntun Cara Modern Menganalisis Tumbuhan. Penerbit ITB. Bandung.

Herawati M.H., Ghani L., 2009. Hubungan Faktor Determinan dengan Kejadian Tifoid Di Indonesia Tahun 2007 (Association of Determinant Factors with Prevalence of Typhoid in Indonesia). 19 (4), 165-173.

Jawetz, Melnick, Adelbergs, 2001. Mikrobiologi Kedokteran. Edisi 20, Salemba Medika, Jakarta, 188-193.

Kumala S., Indriani D., 2008. Efek Antibakteri Ekstrak Etanol Daun Cengkeh (Eugenia aromatic L.). Jurnal Farmasi Indonesia. 4 (2), 82-87.

Kusumowati, I., T., D., Febriani, R., Harianto, F., H., 2017. Skrining Aktivitas Antibakteri Ekstrak Etanol Daun Tanaman dan Kulit Buah Beberapa Tanaman Terhadap Salmonella typhi. Laporan Penelitian. Universitas Muhamamdiyah Surakarta.

Lau K.Y., Zainin N.S., Abas F., Rukayadi F., 2014. Antibacterial and Sporicidal Activity of Eugenia polyantha Wight against Bacillus cereus and Bacillus subtilis. International Journal of Current Microbiology and Applied Sciences. 3 (12), 499510.

Ivana, M., Lidilhone, H., Walmir, S., Ana, L., Marilene, R., Vali, J., 2012. Antimicrobial Activity of some Medical Plants from the Cerrado of the Central Western Region of Brazil. Brazilian Journal of Microbiology. 1302-1308.

Meiske, L., Jaenanette, M., Fetty, I., Amelia, W., Judith, M., Edi, S., 2014. Aktivitas Antifotooksidan dan Komposisi Fenolik Dari Daun Cengkeh (Eugenia aromatic L.). Balai Riset dan Standarisasi Industri. 7 (2), 96-105.

Ivana, M., Lidilhone, M., Walmir, S., Ana, L., Marilene, R., Vali, J., 2012. Antimicrobial Activity of some Medical Plants from the Cerrado of the Central Western Region of Brazil. Brazilian Journal of Microbiology. 1302-1308.

Kumala S., Indriani D., 2008. Efek Antibakteri Ekstrak Etanol Daun Cengkeh (Eugenia aromatic L.). Jurnal Farmasi Indonesia. 4 (2), 82-87.

Kusumowati, I.T.D., Fevriani, R., Harianto, F.H., 2017. Skrining Aktivitas Antibakteri Ekstrak Etanol Daun Tanaman Dan Kulit Buah Beberapa Tanaman Terhadap Salmonella Thypi. Laporan Penelitian PID. Universitas Muhammadiyah Surakarta. 
Lau K.Y., Zainin N.S., Abas F., Rukayadi F., 2014. Antibacterial and Sporicidal Activity of Eugenia polyantha Wight against Bacillus cereus and Bacillus subtilis. International Journal of Current Microbiology and Applied Sciences. 3 (12), 499510.

Lili, M., Fuad, A., Ascobat, G., Pratiwi, A., 2004. Pola Pemberian Antibiotik Pengobatan Demam Tifoid Anak Di Rumah Sakit Fatmawati Jakarta Tahun 20012002. Jurnal Makara Kesehatan. 8 (1), 27-31.

Prasetyo A.D., Sasongko H., 2014. Aktivitas Antibakteri Ekstrak Etanol 70\% Daun Kersen (Muntingia calabura L.) Terhadap Bakteri Bacillus subtilis dan Shigella dysenteriae. Jupemasi-pbio. 1 (1), 98-102.

Shodikin, M.A., 2010. Antimicrobial Activity Of Mahkota Dewa (Phaleria Macrocarpa (Scheff). Boerl.) Leaf Extract Against Pseudomonas Aeruginosa By Agar Dilution And Scanning Electron Microscopy. Folia Medica Indonesia. 46 (3), 172-178.

Sondang, S., Satari H.I., 2010. Pilihan Terapi Empiris Demam Tifoid pada Anak: Kloramfenikol atau Sefriakson. Sari pediatri. 11 (6), 434-439.

Sukandar D., Radiastuti, N., Utami, S., 2010. Aktivitas Antibakteri Ekstrak Butanol Daun Mengkudu (Morinda citrifolia L.). UIN Syarif Hidayatullah. 240-245.

Suresh, P., Deepa, R., Harisaranraj, Vaira, A., 2008. Antimicrobial and Phytochemical Investigation of the Leaves of Carica papaya L., Cynodon dactylon (L.) Pers., Euphorbia hirta L., Melia azedarach L. and Psidium guajava L. Ethnobotanical Leaflets. 12, 1184-1191.

Talahatu, D.R., Papilaya, M., 2015. Pemanfaatan Ekstrak Daun Cengkeh (Syzygium aromaticum L.) Sebagai Herbisida Alami Terhadap Pertumbuhan Gulma Rumput Teki (Cyperus rotundus L.). Biopendix. 1, 149-159.

Wagner, H., Bladt, S., 1996. Plant Drugs Analysis: A Thin Layer Chromatography Atlas. Second edition. Germany, Springer.

Wiart C., Hannah A., Yassim M., Hamimah H., Sulaiman M., 2004. Antimicrobial Activity of Acalypha siamensis Oliv. x Gage. Journal of Ethnopharmacologi. 1, 285-286.

Widoyono, 2008. Penyakit Tropis Epidemiologi, Penularan, Pencegahan \& Pemberantasannya. Penerbit Erlangga. Jakarta. 73.

Yatnita, C.P., 2011. Bakteri Salmonella typhi dan Demam Tifoid. Jurnal Kesehatan Masyarakat. 6 (1), 42-45.

Yuliani, R., Indrayudha, P., Rahmi S.S., 2011. Aktivitas Antibakteri Minyak Atsiri 
Daun Jeruk Purut (Citrus hystrix) Terhadap Staphylococcus aureus dan Escherichia coli. Pharmacon. 12 (2), 50-54. 